\title{
Determining Specific Window Period for Common Scab Disease Infection in Potato Tubers
}

\author{
Bhim Bahadur Khatri ${ }^{1 @}$, RS Tegg ${ }^{2}$, Philip H Brown ${ }^{3}$ and CR Wilson ${ }^{2}$ \\ ${ }^{1}$ Nepal Agricultural Research Council, Khumaltar, Lalitpur, Nepal. @: bhim_khatri@hotmail.com \\ ${ }^{2}$ University of Tasmania, Tasmania, Australia. \\ ${ }^{3}$ Central Queensland University of Queensland, Australia. <p.h.brown@cqu.edu.au>
}

Received February 2016, Revised October 2016, Accepted April 2017, Published May 2017

Scientific Editors: Samudra Lal Joshi, Umesh Acharya

Copyright @2017 NARC. Permits unrestricted use, distribution and reproduction in any medium provided the original work is properly cited

\begin{abstract}
A series of experiments was conducted under glasshouse and hydroponic conditions to determine the specific window period for common scab disease infection in potato tubers. The study was performed in a glasshouse system where separate tubers from the root zone were inoculated at different intervals during plant growth along with a novel hydroponic system to inoculate individual tubers at specific times of development growth allowing non-destructive observations of common scab symptoms developing. The window of tuber susceptibility to common scab disease infection was shown to vary with the season or conditions under which the plants were grown. Different internodes on tubers were found susceptible to infection at different times during tuber development. Basal internodes, which are the first sections of the tuber to expand, were susceptible to infection in the beginning of tuber development, whereas apical internodes only became susceptible later in tuber growth when the basal internodes were no longer susceptible.
\end{abstract}

Keywords: Common scab disease, hydroponic system, infection window, potato

सारांश

आलुको दानामा लाग्ने साधारण दाद रोगले आक्रमण गर्ने समय पत्ता लगाउने हेतुले शिशाघरमा र हाइड्रोपोनिक अवस्थामा श्रृंखलाबद्ध तरिकाले विभिन्न परीक्षणहरु संचालन गरिए। यो परीक्षणमा शिशाघरमा आलुका दानाहरु जरा प्रणालीबाट बोट नमर्ने गरी अलग्याउने र रोगका जीवाणुहरु फरक फरक समयमा संक्रमण गराउने र बोटलाई कुनै क्षति नपुच्याई रोगको अध्ययन गरियो। आलुको दानामा दादका जीवाणुहरु प्रवेश गर्ने समय, आलु रोप्ने समय र बोटहरुको बृद्धि हुने समयमा धेरैनै निर्भर रहेको पाइयो। दानाको विकासको समयमा विभिन्न आँख्लाहरु विभिन्न समयमा रोगका जीवाणुहरुबाट संक्रमित हुन सक्ने पाइयो । सबभन्दा मुनिको आँख्ला जुन सबै भन्दा पहिले बन्ने गर्दछ, सर्वप्रथम संक्रमित हुने पाइयो भने, टुप्पो तिरको आँख्ला जुन अन्तिमा बन्ने गर्दछ, सबभन्दा पछाडि संक्रमित भएको पाइयो जुन बेला सबभन्दा मुनिको आँख्लाको संकमण हराई सकेको हुन्छ।

\section{INTRODUCTION}

Common scab disease (Streptomyces scabiei) of potato has been one of the most important limiting factors throughout the potato growing areas of the world. Various methods of disease management including varietal resistance (Pemberton 1994), chemical treatments (Davis et al 1974), organic amendments (Huber and Watson 1970), strategic irrigation (Lapwood and Adams 1973), crop rotation and soil treatment (Hooker 1990) have been recommended so far. However, even after several decades of efforts, none of the measures have been able to provide an effective control of the scab disease. Studies showed that the earlier stages of the tuber development as the key stage for common scab disease infection and natural openings like lenticels existing on the tuber could be entry routes for Streptomyces (Agrios 2005, Guest and Brown 1997, Khatri et al 2013).

Growth of the tuber depends primarily on expansion of internodes and tuber growth stops after detaching from or death of the parent plant. Stomata, lenticels and new epidermis/periderm formation are potential entry sites for the pathogen. Therefore, studies on simple tuber physiological structure do not give an accurate estimate of tuber susceptibility (Lapwood and Hering 1970). Probably due to this reason, the severity of common scab disease varies from internode to internode, cultivar to cultivar, field to field over years. No clear explanation for the apparently erratic and uneven distribution of this disease is clear even within a field (Conn et al 1998). 
The appearance of stomata in unexpanded internodes in the tubers even at very late stage, and availability of lenticels in epidermis at very early stage, indicates the possibility of infection window active for long period (Lapwood and Adams 1973, Lapwood and Dyson 1966, Lapwood and Hering 1970, Khatri et al 2011). Knowledge on host-pathogen interactions, physiological basis for window of susceptibility to common scab disease during tuber development are poorly known (Lapwood and Dyson 1966, Wanner 2008). However, most of the past research showed that scab infections occur during the early stages of growth and development stages of potato tubers especially on actively growing areas of the tuber, the window period for infection remains uncertain (Lawerence et al 1990). Therefore, an effort is made to investigate the relationship between tuber infection at different dates of pathogen inoculation, interactions between internodes and pathogen inoculation dates, physiological development of the plant at disease infection and main structural features at the day of inoculation. The experiment was designed to test the hypothesis that tuber remains susceptible to scab infection only for short period of time and later on resistance develops inside the tuber and as a result infection cannot occur.

\section{MATERIALS AND METHODS}

One pot experiment under glasshouse conditions and two hydroponics trials were conducted at University of Tasmania, Tasmania, Australia to determine the specific window period for common scab disease infection in potato tubers. Experiments conducted to facilitate the exposure of plants to the pathogen at specific times during plant growth or exposure of individual tubers at defined tuber ages or stages of development. Surface area of the tuber was approximated as an ellipsoid, spherical and round function following Khatri et al (2010).

\section{Experiment 1: Effect of different dates of pathogen inoculation on common scab disease development}

Using a modification of the McIntosh (1970) methodologies, sixty 5L (200 x 200 mm) plastic bags containing a compartmented system designed to separate the root system and tubers were filled to $40 \%$ capacity with standard potting mix following Khatri et al (2011). Over this, a $40 \mathrm{~cm}^{2}$ piece of screen fibre glass mesh (1 mm) was placed and each piece was used to create a bowl shaped zone in a planting bag. On top of this, a vermiculite-potting soil mixture at 1:1 was added, filling the bag to $80 \%$ capacity. After the preparation of the pots, gentle hand-watering was used to moisten and settle the potting mix. To each pot one two-week old tissue-cultured plantlet of Desiree variety was planted, carefully placing the roots on the mesh in the upper zone of the pots, and gently watered. During plant establishment, small plastic vials were placed over plants for 1 week to reduce transplant stress. Irrigation was initially deep and infrequent to encourage root penetration through mesh into bottom soil layer. As plants developed a vermiculite-potting soil (1:1) mixture was used to top-up, preventing exposure of developing tubers to external environment.

New root growth from the tissue-cultured plantlets rapidly penetrated the upper zone and grew through the mesh into the lower layer of potting mix. Stolon and tuber growth was restricted to the upper zone. From 30 days after planting (DAP), plants were destructively harvested at regular intervals (additional plants were planted for this purpose) to determine the time of tuber initiation. Swelling of the stolon in the sub-apical region was considered as the first observable sign of tuberization (Cutter 1992, Xu et al 1998) and stolon was considered tuberized, if the tip was measured more than twice in the diameter of expanding stolon (Ewing 1990). At day 45, tubers were found on 3 harvested plants, and this date was defined as the time of tuberization. Seventy uniform sized plants were selected for the experiment, which involved seven inoculation date treatments. Plants were labelled and arranged in a completely randomised block design prior to application of inoculation treatments.

Seven separate inoculation dates: 14, 21, 28, 35, 42, 49 and 56 day after transplantation (DAT) (60-102 DAP) were applied to Desiree plants. The treatments were replicated $(n=5)$ in a completely randomized design with a pair-wise comparison at treatment date. At each specific inoculation treatment date, plants of similar size were selected randomly. With care the top layer of potting media above the mesh was removed by turning the pot upside down and gently tapping, this process was facilitated by keeping upper soil layer dry. This excluded exposed developing stolons and tubers, ready for either harvest, pathogen and/or control treatments.

At each inoculation date, ten plants were used, and they were grouped into pairs ( 5 replicates by 2 ). One plant from each pair had five different representative sized tubers selected, with each tuber measured for length, width and marked with a tag; taking care not to damage the plant. The other paired plants were harvested, with five corresponding tubers matching size dimensions of the other pot washed gently in tap water, wiped with tissue paper and kept in formalin acetic acid for histological studies. The tagged plants were then re-filled with inoculated vermiculite-potting soil (1:1) mixture, above the 
mesh, irrigated immediately and placed back into the glasshouse in the randomized design. After treatment, plants were managed in a manner that encouraged thorough drying of the soil media between irrigations, so as to encourage common scab symptom development.

\section{Experiment 2: Effect of early, medium and late inoculations and two moisture treatments (dry and wet) on disease} infection under hydroponics

Two novel hydroponic trials were managed with the nutrient outlet flow rate of $125 \pm 5 \mathrm{ml}$ per minute having a $\mathrm{pH}$ in the nutrient solution of 6 to 7. Two-week old tissue-cultured plantlets of Desiree were planted in the hydroponic system following methods described by Khatri et al $(2010,2013)$. There were six separate benches and nine plants planted per bench. Planting date was optimized based on Yang (2004) so as to ensure adequate numbers of growing stolons and tubers forming. Where short stolons formed and were of no use, they were removed to encourage subsequent stolon growth and tuberization. The aim was to have approximately 50 similar-age tubers per bench (300 in total) at any one time for experimental usage.

In first trial, 3 separate inoculation dates: 10, 20 and 30 DAT were applied to Desiree tubers. Each separate inoculation date consisted of 1 spray only. Additionally, moisture conditions upon which the tubers were lying, a wet hydroponic mat treatment versus a dry environment in petri dishes free of surface water, was another factor studied. A total of one hundred and fifty tubers were used in the wet treatment and three hundred were used for the dry treatment. The experiment was setup in an unbalanced block design with 3 plants per bench being allocated for each inoculation treatment date.

On the day of treatment, pathogen was prepared by scraping the surface of 5 fully colonised ISP2 slopes and rinsing twice with distilled water. The water rinsing, containing spores and mycelia, was made up to $250 \mathrm{ml}$ and placed in a spray bottle ready for application. The tubers in groups of ten were then sprayed thoroughly with the appropriate treatment (pathogen or water control), wetting the whole surface of the tuber. Paper was placed around the groups of tubers to prevent spray drift. Control sprays of water only were applied randomly across all replicates (minimum of 10 tubers per bench). All tubers were harvested at senescence (130 DAP); the individual tagged tubers were measured again for their size (surface area) increase, weighed and assessed for common scab infection and scab severity on whole tuber. Harvest and tuber assessment was performed at plant senescence.

In second trial, 3 separate inoculation dates: 0-10, 11-20 and 21-30 DAT were applied to Desiree tubers. Each separate inoculation date consisted of 2 sprays at 5 day intervals i.e. for 0-10 DAT treatment sprays were made at days 3 and 8 . Each treatment was made to 10 separate tubers per bench $(n=6)$ giving 60 tubers per treatment. Water spray controls were also made to 10 tubers per bench.

A few days prior to pathogen application, developing stolons and tubers were selected and carefully positioned into groups of ten ready for treatment application. Individual tubers were marked on the day of tuberization (diameter of stolon tip twice that of the subtending stolon). In trial \# 1, 150 tubers were left on the hydroponic mat (wet treatment) and 300 were positioned in petri plates with dry matting underneath (dry treatment). In trial 2, tubers were positioned in petri plates with dry matting underneath. Also, nutrient flow rate was reduced from 120 down to $60 \pm 5 \mathrm{ml}$ per minute, and was kept at this level for the remainder of the experiment. Harvest and tuber assessment of this trial was also performed at plant senescence.

Common scab lesion severity was assessed using the modified rating scale of Bjor and Roer (1980) as:

$0=$ no disease; $1=$ superficial or slightly raised lesions $<1 \mathrm{~mm}$ deep; $2=$ lesion $>1 \mathrm{~mm}<2 \mathrm{~mm}$ deep; $3=$ lesion $>2 \mathrm{~mm}<3 \mathrm{~mm}$ deep; 4 = lesion $>4 \mathrm{~mm}$ deep

The incidence and percentage of scab on the surface of each tuber was estimated using the method of Richardson and Heeg (1954).

$$
0=\text { No disease } ; 1 / 2=0-1 \% ; 1=1-5 \% ; 2=5-10 \% ; 3=10-30 \% ; 4=30-50 \% ; 5=50-70 \% ; 6=70-100 \%
$$

Where analysis of data required an average plant or pot score and there was more than one tuber per pot an average incidence and/or percentage scab was calculated using the formula below:

$(\# C A T 0 \times 0)+(\# C A T 1 / 2 \times 1 / 2)+(\# C A T 1 \times 1)+(\# C A T 2 \times 2)+(\# C A T 3 \times 3)+(\# C A T 4 \times 4)+(\# C A T 5 \times 5)+(\# C A T 6 \times 6)) /$ (Total tuber number) where, CAT is Cutaneous Assessment Tool, 
An analysis of variance and least significant difference (LSD) procedure using SAS for windows was performed to treatment effects in the three experiments.

\section{RESULTS}

Experiment 1: Effect of different dates of pathogen inoculation on common scab disease development in Desiree potato variety under glasshouse conditions

The date of inoculation with the common scab pathogen had a highly significant ( $\mathrm{p}<0.001)$ impact on infection rate of potato tubers (Figure 1). Tubers inoculated at $60 \mathrm{DAP}$ or 2 weeks after tuberization were infected to a greater extent than all other inoculation date treatments, with mean tuber infection percentage of $68 \%$. Percentage infection of tubers at 67 DAP inoculation was $60 \%$, with infection rate declining sharply to $28 \%$ at day 74 inoculation and then decreasing more gradually to a final level of $4 \%$ infection at 102 DAP inoculation.

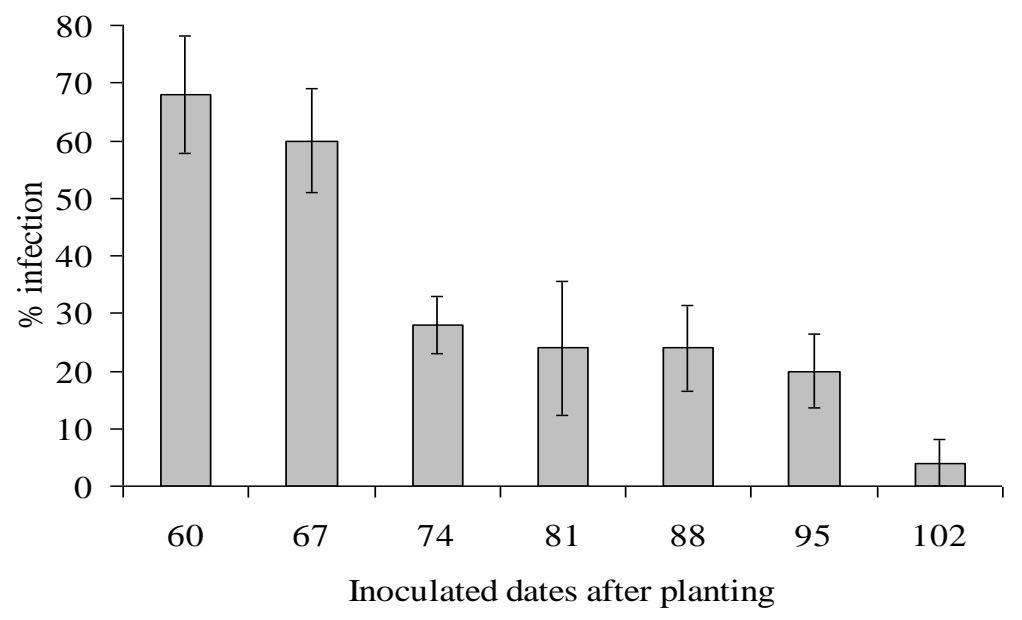

Figure 1. Tuber infection (\%) from different date of pathogen inoculation (approximately 2, 3, 4, 5, 6, 7, and 8 weeks after tuberization) in Desiree potato variety. Bar corresponds to standard error of the mean ( $n=25$ tubers).

A highly significant $(\mathrm{P}<0.001)$ difference in the percentage of tubers infected was found between inoculation date treatments, indicating a window of high susceptibility to common scab disease infection in the tuber at 60 to 67 days after planting, or about 2 to 3 weeks after tuberization. Tuber exposure to the pathogen after this period of high susceptibility led to few tubers being infected. Lower infection rates occurred at later inoculation dates, demonstrating that while susceptibility decreased with plant (and presumably tuber) age the window in which infection can occur extended over the duration of the tuber growth and development period. 


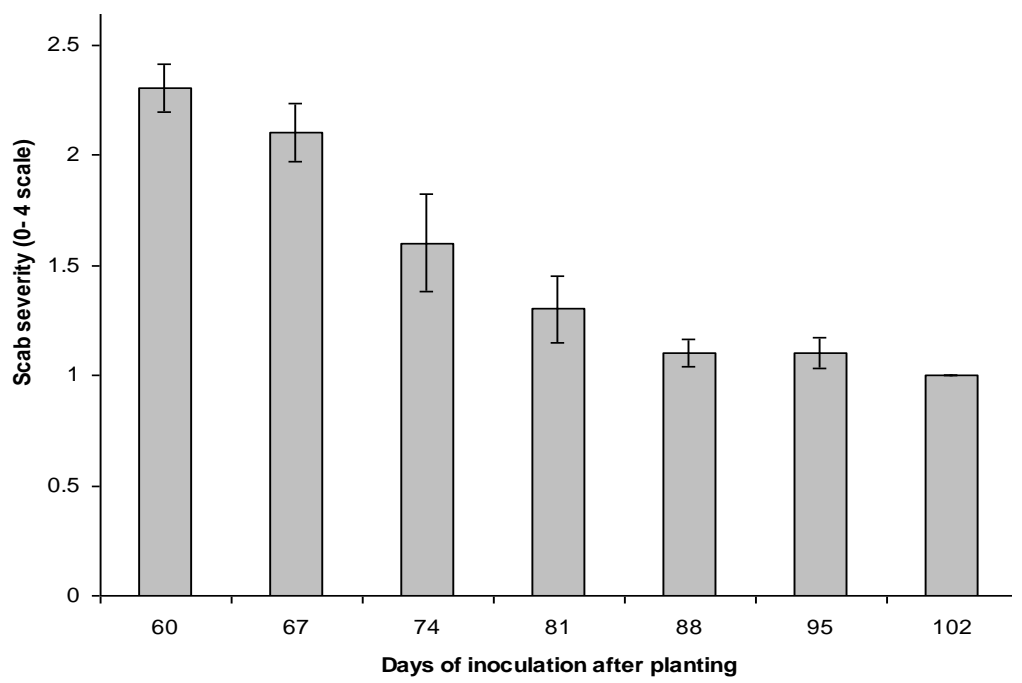

Figure 2. Differences in scab severity on the tubers at different days of pathogen inoculation after planting, (approximately 2, 3, 4, 5, 6, 7 \& 8 weeks after tuberization), cv Desiree. Bar corresponds to standard error of the mean ( $\mathrm{n}=25$ tubers).

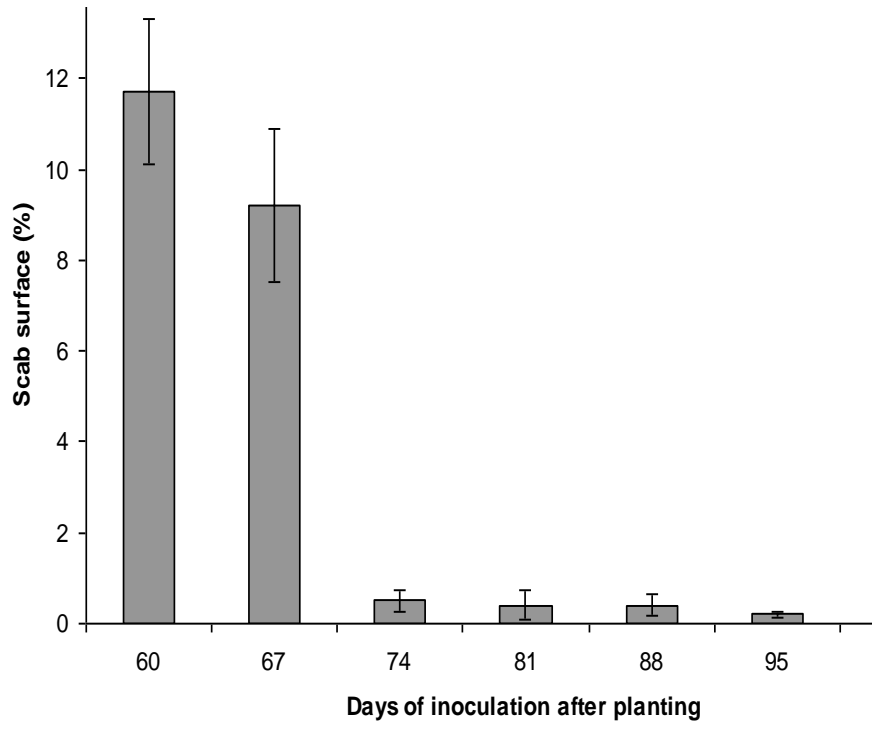

Figure 3. Percentage common scab infection on the tubers as influenced by the days after planting, (approximately 2, 3, 4, 5, 6, $7 \& 8$ weeks after tuberization), cv Desiree. Bar corresponds to standard error of the mean ( $\mathrm{n}=25$ tubers).

Scab severity, measured as lesion depth assessed on a visual scale of 0 to 4 , followed a similar trend to infection percentage (Figure 2). The severity of common scab lesions was greatest at the first inoculation date and declined with later inoculation dates.

The effect of inoculation date on scab severity was highly significant $(P<0.001)$. The most severely affected tubers were obtained in the day 60 inoculation treatment, with the mean severity rating of 2.3 representing scab lesions of between lesion depth of $>1 \mathrm{~mm}$ to $<2 \mathrm{~mm}$ depth. Mean severity rating declined with later inoculation dates and by day 88 , inoculation resulted in only superficial scab lesions on the tubers.

Inoculation at the earliest dates provided a longer time period for development of lesions in comparison to later inoculation dates, and this difference in duration of exposure to the pathogen may have contributed to the recorded trend in scab severity. Almost all tubers inoculated at day 60 and 67 (2 and 3 weeks after tuberization, respectively) were scored as having a scab severity more than 2 , demonstrating that severe symptoms could develop within 63 to 70 days of inoculation or 8 to 10 weeks after tuberization, suggesting that the reduced severity of symptoms with later inoculation dates was at least partially 
attributable to reduce susceptibility of tubers to disease development. The highest severity rating for a tuber inoculated at day 95 was 2 out of 4 and disease infection at 102 days inoculation provided further support for this conclusion.

The effect of inoculation date on the percentage of tuber surface area covered by scab lesions was highly significant $(\mathrm{P}<0.001)$, with approximately $12 \%$ and $9 \%$ of tuber surface area covered by lesions when inoculated at 60 and 67 days after planting, respectively. This declined to less than $1 \%$ with all the later inoculation dates (Figure 3). No significant difference was observed between inoculation treatments on days 74 to 102, with few lesions present on tubers from each of these later inoculation date treatments.

Experiment 2: Effect of early, medium and late inoculations and two moisture treatments (dry and wet) on disease infection under hydroponics

In first trial, individual tubers of cultivar Desiree were successfully infected with common scab in the hydroponic system using the methodology developed by Khatri et al (2010). None of the control tubers, sprayed with distilled water rather than inoculum, displayed scab lesions, indicating that the symptoms observed were the result of pathogen infection rather than the growing conditions or inoculum application method. Tuber susceptibility to infection, and the severity of common scab symptoms developing on infected tubers, was found to vary with tuber age (Table 1). The highest infection percentage, about $37 \%$ of inoculated tubers, was recorded when tubers were inoculated 20 days after they had tuberized.

Tuber surface scabbed was highest (3.8 \pm 0.8$)$ on second inoculation and no differences between first and third inoculation. The severity of scab symptoms on infected tubers did not vary significantly $(\mathrm{P}<0.001)$ between inoculation date treatments, and was low in comparison to the tubers in the glasshouse trial, however, the earlier tubers were inoculated, the slightly higher was the lesion severity observed in the results.

Tuber size (surface area) at harvest, along with number of expanded internodes per tuber, was highest on the tubers inoculated at $30 \mathrm{DAT}$. As infection percentage was lowest for this treatment, it is possible that common scab infection reduced the rate of tuber growth.

Table 1. Main effect of inoculation date on tuber size, number of expanded internodes/tuber, \% common scab infection and scab symptom severity on tubers of Desire variety

\begin{tabular}{llllll}
\hline Inoculation date $(\mathrm{DAT})$ & Tuber size $\left(\mathbf{c m}^{2}\right)$ & Internode $/$ tuber $(\#)$ & Infected tubers $(\%)$ & Scab surface $(\%)$ & Scab severity \\
\hline 10 & $17.22 \pm 1.11$ & $6.7 \pm 0.1$ & 15.5 & $0.4 \pm 0.1$ & $1.6 \pm 0.2$ \\
20 & $12.53 \pm 0.39$ & $6.5 \pm 0.1$ & 36.6 & $3.8 \pm 0.8$ & $1.5 \pm 0.1$ \\
30 & $20.63 \pm 1.02$ & $8.8 \pm 0.4$ & 8.4 & $0.3 \pm 0.2$ & $1.4 \pm 0.3$ \\
F-probability & $<.0001$ & $<.0001$ & & $<.0001$ & NS \\
LSD $(\mathrm{P}<0.05)$ & 2.20 & 0.470 & & 1.707 & 0.598 \\
\hline
\end{tabular}

Average number of internodes per tuber was counted higher on wet (normal hydroponic condition treatment) than dry (tubers growing on petri plates). Effect of treatments on tuber sizes and the relationships between scab inoculations with disease infection supported further confirmation (Table 1 and 2) towards the effect of scab on tuber size and yield.

In second trial, higher tuber infection rates were recorded in the second hydroponic experiment, with two thirds of inoculated tubers being infected at the first inoculation date. The percentage of tubers infected declined with increasing tuber age and the effect was statistically significant at $\mathrm{P}<0.05$ level (Table 3 ).

The severity of symptoms on inoculated tubers also decreased with increasing tuber age at inoculation, with a significant $(\mathrm{P}<0.001)$ decrease in the surface area of tubers affected by scab lesions and a trend towards decreased depth of lesions assessed visually using the 0 to 4 scab severity scale. In contrast to the previous experiment, tuber size at harvest was not significantly affected by the inoculation treatments.

Table 3. Effect of pathogen inoculated days on tuber size, common scab incidence, scab surface (\%) and scab severity on the tubers

\begin{tabular}{lcccc}
\hline \multicolumn{1}{c}{ Inoculation date } & $\begin{array}{c}\text { Tuber size (Surface area } \\
\left.\mathbf{c m}^{\mathbf{2}}\right)\end{array}$ & Scab surface $(\boldsymbol{\%})$ & Scab severity $(\mathbf{0 - 4}$ scale) & $\begin{array}{c}\text { Tuber infected } \\
(\boldsymbol{\%})\end{array}$ \\
\hline $1^{\text {st }} \mathrm{I}(0-10 \mathrm{DAT})$ & $15.7 \pm 1.7$ & $4.6 \pm 1.3$ & $1.5 \pm 0.1$ & $66.6 \pm 7.1$ \\
$2^{\text {nd }}(10-20 \mathrm{DAT})$ & $16.8 \pm 1.3$ & $1.7 \pm 0.5$ & $1.2 \pm 0.1$ & $52.6 \pm 12.2$ \\
$3^{\text {rd }}(20-30$ DAT $)$ & $19.1 \pm 1.5$ & $1.2 \pm 0.6$ & $1.1 \pm 0.1$ & $26.6 \pm 11.4$ \\
\hline F-probability & $\mathrm{NS}$ & 0.0119 & $\mathrm{NS}$ & 0.0479 \\
LSD $(\mathrm{P}<0.05)$ & & 2.3518 & & 31.538 \\
\hline
\end{tabular}


There was no significant $(\mathrm{P}<0.001)$ treatment effect on scab severity on different inoculation dates, however, the earlier the inoculation, the higher was the scab severity found (Table 3). Inoculation dates had a significant effect $(\mathrm{P}<0.05)$ on percent tuber infection. The tubers inoculated at 0 to $10 \mathrm{DAT}$ were $66.6 \pm 7.1 \%$ infected with common scab disease followed by 10 to 20 DAT inoculation $(52.6 \pm 12.2 \%)$ and 20 to 30 DAT inoculation $(26.6 \pm 11.4 \%)$.

\section{DISCUSSION}

The main window of tuber susceptibility to common scab disease infection occurred in the early stage of tuber formation. Similar results have also been shown in earlier literatures related to the potato tuber and scab infection such as Adams and Lapwood (1978), Hide and Lapwood (1992), Loria et al (2003). They have reported that the developing portion of the tuber is most vulnerable and severity increases as the tubers swell. Also, from field experiments, Lapwood and Hering (1970) have reported infection occurring only on actively growing tubers or parts of tubers.

Highest common scab infection and disease severity was recorded when plants were inoculated at 60 DAP, i.e. 2 weeks after tuberization (WAT), followed by 67 DAP. After 74 DAP or 4 WAT the infection reduced sharply (Figure 2 and 3). However, the infection seen on the tubers inoculated at even 102 DAP i.e. 8 WAT is in agreement with the results of Park et al (2003) who reported common scab infection occurring at a later stage of tuber development. The disease occurred 60 days after planting in spring and 40 days in autumn, but highest percent of disease incidence at 70 days after planting in both the seasons. This finding is not in line with that of Lapwood and Dyson (1966), and Stalham and Firman (1996), who reported that the critical period for scab was before or during the period when tubers were being initiated and lasting only for few weeks depending on the rate of tuber growth and development but not occurring on mature tubers. Regarding the severity, the earlier a tuber becomes infected the larger the scab lesion and higher the severity. Hooker and Page (1960) have documented most scab infection occurring during the early stages of growth and development; however, actively growing areas of the tuber having stomata or unsuberized lenticels might susceptible to infection throughout the growing season. In summary, methods and results described in this paper might expand the knowledge on different methodologies of successful experimentation, thus expands the current understanding of infection window of the tubers..

\section{ACKNOWLEDGEMENTS}

Thanks to all scientists, technical officers and staffs working in National Potato Research Program, Khumaltar, Lalitpur, Nepal. Partial fund for the study was supported by Nepal Agricultural Research Council.

\section{REFERENCES}

Adams MJ and DH Lapwood. 1978. Studies on the lenticel development, surface microflora and infections by common scab (Streptomyces scabies) of potato tubers growing in wet and dry soils. Annals of Applied Biology 90:335-343.

Adams MJ. 1975. Potato tuber lenticels: development and structure. Annals of Applied Biology 79:265-273.

Agrios GN. 2005. 'Plant Pathology-5th Ed.' (Elsevier Academic Press: California, USA)

Bjor T and L Roer. 1980. Testing the resistance of potato varieties to common scab. Potato Research 23: 33-47

Conn KL, E Leci, G Kritzman and G Lazarovits.1998. A quantitative method for determining soil populations of Streptomyces and differentiating potential potato scab-inducing strains. Plant Disease 82:631-638.

Cutter E. 1992.Structure and development of the potato plant. In: 'The Potato Crop: the scientific basis for improvement'. (PM Harris, eds) (Chapman \& Hall).Pp.65-161.

Davis JR, JG Garner and RH Callihan. 1974. Effects of gypsum, sulfur, terraclor and terraclor super-X for potato scab control. American Potato Journal51:35-43.

Ewing EE. 1990.Induction of Tuberization in potato (Solanumtuberosum L.).In: Molecular and Cellular Biology of the potato '. (Kluwer Academic Dordrecht)

Guest D and J Brown. 1997. Plant defenses against pathogens. In: 'Plant Pathogens and Plant Diseases'. (JF Brown and HJ Ogle, eds) (Rockvale Publications). Pp. 263-286.

Hide G A and D H Lapwood. 1992. Disease aspects of potato production. In: 'The Potato Crop: The Scientific Basis for Improvement'. (P Harris, eds) (Chapman \& Hall). Pp.403-437.

Hooker WJ and OT Page, 1960. Relation of potato tuber growth and skin maturity to in-fection by common scab, Streptomyces scabies. Am. Potato J. 37: 414-423.

Hooker WJ. 1990. Common scab. In: 'Compendium of potato diseases' (The American Phytopathological Society).

Huber DM and R D Watson. 1970. Effects of organic amendment on soil-borne plant pathogens. Phytopathology39:387-392. 
Khatri BB, RS Tegg, PH Brown and CR Wilson. 2010. Infection of potato tubers with the common scab pathogen Streptomyces scabiei in a soil-less system. Journal of Phytopahtology 158:453-5.

Khatri BB, RS Tegg, PH Brown and CR Wilson. 2011. Temporal association of potato tuber development with susceptibility to common scab and Streptomyces scabiei-induced responses in the potato periderm. Plant Pathology 60:1-11.

Khatri BB, P Brown, R Tegg and C Wilsonan. 2013. Do All Lenticels on Potato Tubers Form from Stomata? Nepal Agriculture Research Journal 13:25-34.

Lapwood DH and MJ Adams. 1973. The effect of a few days of rain on the distribution of common scab (Streptomyces scabies) on young potato tubers. Annals of Applied Biology 73:277-283.

Lapwood DH and PW Dyson. 1966. An effect of nitrogen on the formation of potato tubers and the incidence of common scab (Streptomyces scabies). Plant Pathology15:9-14.

Lapwood DH and TF Hering. 1970. Soil moisture and the infection of young potato tubers by Streptomyces scabies (common scab). Potato Research13:296-304.

Lawrence CH, MC Clark and RR King. 1990. Induction of common scab symptoms in aseptically cultured potato tubers by the vivotoxin, thaxtomin. Phytopathology80:606-608.

Loria R, J Coombs, Y Masahiro, K John and B Raghida. 2003. A paucity of bacterial root diseases: Streptomyces succeeds where others fail. Physiological and Molecular Plant Pathology 62:62-75.

McIntosh A. 1970. A glasshouse methods for testing chemicals for control of potato common scab. Potato Research 13:241-7, CrossRef, CAS

Park D, J Kim, S Kwon, C Wilson, Y Yu, J Hur and C Lim. 2003. Streptomyces luridiscabiei sp. nov., Streptomyces puniciscabieisp. nov.andStreptomyces niveiscabieisp. nov., which cause potato common scab disease in Korea. International Journal of Systematic and Evolutionary Microbiology53:2049-2054.

Pemberten B. 1994.The influence of green manure and crop rotation on common scab. In: Integrated control of common scab, A compilation of working documents (C. Wilson, D. Fulton and B. Pemberten, eds).

Richardson JK, Heeg TJ (1954) Potato common scab investigations 1: a survey of disease incidence in Southern Ontario. Canadian Journal of Agricultural Science 34, 53-59.

Stalham MA, Firman DM. 1996. Control of common scab by manipulating frequency, duration and quantity of irrigation. $\bullet$ Abstracts of the $13^{\text {th }}$ Triennial Conference of the European Association for Potato Research. Veldhoven, The Netherlands 1996, p. 674-5.

Wanner LA. 2009. A patchwork of Streptomyces species isolated from potato common scab lesions in North America. Am J Potato Res 86(4):247-264

Xu X, D Vreugdenhil and AAM van Lammeren. 1998. Cell division and cell enlargement during potato tuber formation. Journal of Experimental Botany320:573-582.

Yang S. 2004.Potato Tuberization in Hydroponics.PhD thesis, University of Tasman 